Nurul Tsanaa Lathifah ${ }^{1}$, Moses Glorino Rumambo Pandin ${ }^{2}$

Universitas Airlangga Surabaya, Indonesia

Jl. Airlangga No. 4-6, Mulyorejo, East Java, Indonesia

nurul.tsanaa.lathifah-2020@fkp.unair.ac.id; moses.glorino@ fib.unair.ac.id

\title{
Book Review: Important Character Education in the Covid-19 Era
}

Book title: Important Character Education in the Covid-19 Era: Strengthening Character Education Prepares Peer Tutor Students in the Family neighborhood and Skaa Youth Organization; Author: Putu Beny Pradnyana; Publisher: Surya Dewata (SD); City of Publishing: Bali; Edition: First Print, 2020; Number of pages: viii + 74 pages; Book size: $14 \mathrm{~cm}$ x 20cm; ISBN:978-623-93393-5-7

Character education is a system that aims to shape character by developing the potential in each one to match character values. Character education is structured based on the values contained in Pancasila and the 1945 Constitution. In the beginning, character education was considered not very important, but as the world developed, character education was finally highlighted. Character education is deemed vital because it shapes and develops potential, strengthens and improves, and filters out other things that do not follow the character values in everyday life and Pancasila.

Character education can be a stronghold in various circumstances, even in emergencies such as the Covid-19 pandemic. However, in preventing the spread of Covid-19, many violations of health protocols resulted in unsuccessful character education, so strengthening character education was needed. Strengthening character education aims to improve the harmonization of taste, emotion, mind, and body so that character values are emphasized again.

This book aims to provide solutions regarding strengthening character education, namely by gradually supporting character education to increase awareness of the importance of implementing health protocols and reducing the number of cases infected with Covid-19. The author provides a new perspective on how to strengthen character during the pandemic effectively.

This review aims to inform the contents of the book "Important Character Education in the Covid-19 Era: Strengthening Character Education Prepares Peer Tutor Students in the Family and Ska Youth Organization" to readers so that lessons can be taken so that they can implement in life. This book is intended for all people to increase awareness of health protocols.

The author wrote this book based on a phenomenon that occurred at the end of 2019 when the whole world was panicked because of the emergence of Covid-19 (1). Cases that initially came from Wuhan, China, spread rapidly to various parts of the world. The first case of Covid-19 infection in Indonesia was revealed in March 2020 and continues to increase. The increase in chances of being infected with Covid-19 caused by the lack of discipline in the community towards existing health protocols indicates a decline in one of the values of the third Pancasila principle, namely love for the homeland. This phenomenon occurs because the values of Pancasila have not been appropriately achieved, causing a shift in ethics. Thing like this cannot be allowed continuingly. Therefore this book provides one way to suppress cases of Covid-19 infection by strengthening character education.

The book "Important Character Education in the Covid-19 Era: Strengthening Character Education Prepares Peer Tutor Students in the Family neighborhood and Ska Youth Organization" discusses various aspects of character education both in terms of dimensions, urgency and the history of the formation of character education, the goals of character education, various components that must be achieved in character education, and strengthening character education in the era of the Covid-19 pandemic, especially for students.

At the beginning of the formation of the Indonesian state, character education has not been spotlighted by the government. However, in 2005 and globalization, the modernization and then the government highlighted character education as something that must be considered in the vision and direction of long-term development. Indonesian character education is structured based on the values contained in Pancasila and the 1945 Constitution. Character education is structured in such a way as to form a system that aims to instill character values following by Pancasila and the 1945 
Constitution. With its aim, character education has several functions when viewed from various points of view. First to establish and develop potential, second to strengthen and improve, third to filter out other things that do not match the character values. The components of character that must be achieved in character education are competence, desire, habits. These three things indicate the success of character education.

The success of character education is highly dependent on the success of the learning process. Nevertheless, when all activities, even education, are shifted to online, the character education that should be delivered fully becomes like a passing wind that passes without being firmly embedded. The addition of cases infected with Covid-19 due to many violations of health protocols committed mainly by the young generation was happened because of degradation character education. Violations of health protocols that occur show that character education is not achieved during this pandemic. Character education with components such as the emergence of a desire to jointly protect the Indonesian people from Covid-19, the habit of obeying health protocols that indicate the success of character education in this pandemic era, in reality, does not work. Therefore, it is necessary to strengthen character education (1).

Strengthening character education creates harmony between the heart, taste, mind, and body to emphasize character values to produce future generations with character values. In this book, the author conducts online training to strengthen character education gradually and effectively by delivering material related to character education and then measuring success by filling out questionnaires. The method was successfully proven by the assessment score above average or in the outstanding category. With a high final score, it indicates that character strengthening is very effective. Through strengthening character education, it is hoped that moral awareness and courage will arise in him to prevent the spread of the Covid-19 virus with existing health protocols.

This book describes character education and strengthens character education in every detail, both from the government and expert opinions. The indications for achieving character education are well conveyed, and the character is strengthening training methods during the pandemic to be effective. The language used in this book is very straightforward to understand, covering a wide range of readers.

Character education is a good investment for the future. Character education forms the next generation to take advantage of their potential and abilities with character values following by Pancasila and the 1945 Constitution. One of the most fundamental values is from the third principle of Pancasila Persatuan Indonesia. By implementing the values of the third precepts of Pancasila in various aspects of life such as love for the homeland, prioritizing common interests, being willing to sacrifice, of course will have an impact on the life of the state so that it can develop even more. Even in emergency conditions such as the Covid-19 pandemic, character education can be the first line of defense in protecting oneself. But many violations of health protocols have occurred by the younger generation and have led to an increase in cases of Covid-19 infection, therefore strengthening character education is needed. With the strengthening of character education embedded, it is hoped that courage will arise in making decisions, awareness of the importance of implementing health protocols to maintain the safety of others so that the transmission of Covid-19 can be suppressed.

\section{REFERENCE}

1. Pradnyana, Putu Beny. Pendidikan Karakter Penting di era Covid-19: Penguatan Pendidikan Karakter Mempersiapkan Mahasiswa Tutor Sebaya di lingkungan Keluarga dan Skaa Taruna [Internet]. Bali : Surya Dewata (SD); 2020. 1-74 p.

\section{Author:}

Putu Beny Pradnya, S.Pd., M.Pd. is the eldest son of four children from the couple I Ketut Barki and Ni Wayan Nadi, born on January 8, 1989, Tabanan. He holds a Bachelor of Elementary School Teacher Education and a Masters of Basic Education at the Ganesha University of Education. From 2014 until now, he has been a lecturer at STKIP Suar Bangli. He is also the Head of the Elementary School Teacher Education Study Program since 2018-2022. 